\title{
Politeness Principle in Cross-Culture Communication
}

\author{
Yongliang Huang \\ Foreign Languages Department, Xianyang Normal University, Xianyang 712000, China \\ Tel: 86-29-3372-2670Ｅ-mail: Hyl66xy@126.com \\ The project was supported by the Science Foundation of Xianyang Normal University. (No. 06XSYK101)
}

\begin{abstract}
As we all know, different people hold different views about politeness. To be polite, Leech thinks you should follow "Politeness Principle" while Levinson suggests paying attention to others' "Face Wants". Sometimes what the Chinese people considered to be polite may not be true according to western culture. In order to adequately provide an educated answer to this heartfelt question, this paper attempts to shed light on some of the important differences on politeness between Chinese and western culture and their values.
\end{abstract}

Keywords: Politeness, Culture differences, Politeness principle

\section{Introduction}

In 1978, English scholars Brown\& Levinson wrote an article "Universals in Language Usage: Politeness Phenomena". Soon after that, Leech delivered his six criteria of politeness in 1983. Both of them draw great attention to Politeness. According to Brown\& Levinson " politeness involves us showing an awareness of other people' s FACE WANTS, and FACE refers to our public self- image. There are two aspects to this self-image: One is POSITIVE FACE, the other is NEGATIVE FACE. POSITIVE FACE refers to the want of every member that his wants be desirable to at least some others. [my emphasis]. NEGATIVE FACE refers to the want of every 'competent adult member' [of a society] that his actions be unimpeded by others.

Among Leech's six criteria of politeness, the following six are very important:

(1) Tact-maxim (in impositives and commissives): Minimize the cost to other; maximize the benefit to other.

(2) Generosity maxim (in impositives and commissives): minimise benefit to self,maximise cost to self.

(3) Approbation maxim (in expressives and assertives): minimise dispraise of other, maximise praise of other.

(4) Modesty maxim (in expressives and assertives):minimise praise of self, maximize dispraise of self.

(5) Agreement maxim (in assertives): minimise disagreement between self and other, maximise agreement between self and other.

(6) Sympathy maxim (in assertives): minimise antipathy between self and other, maximise sympathy between self and other.

And in China, serious study of politeness within the linguistic circles did not begin until the early 1980s. According to Chinese history and traditional culture, Mr. Gu Yueguo of Beijing Foreign Studies University have contribute the politeness of study in China. He has traced the origin of the notion of politeness in the Chinese culture, and has also formulated a different kind of politeness maxims, which he thinks are more suitable to the Chinese environment.

$\mathrm{Mr}$. Gu believed that there are basically four aspects of Chinese conception of politeness (we call in Chinese limao): respectfulness, modesty, attitudinal warmth, and refinement. Respectfulness is self's positive appreciation or admiration of other concerning the latter's face, social status, and so on. Modesty can be seemed as another way of saying 'self-denigration'. Attitudinal warmth is self's demonstration of kindness, consideration, and hospitality to other, and Refinement refers to self's behavior to other which meets certain standards. (Gu, 1990)

Theorists have dug in every way to discover the ways to be polite. But there have always been exceptions in the standards put by them and culture difference has been a main source of most of these exceptions.

\section{The Definition of Politeness}

What is politeness? This question seems naive and simple. In our daily life, we have the awareness of what is a polite action or not. For instance, to offer your seat to the elderly on a bus is considered polite behavior, and to interrupt when someone is talking is considered impolite behavior; to greet to someone at the first time when you meet in the morning 
is polite and to stand up to reach for the dish you want at a dinner table is impolite. So first of all, politeness can conceived as an observable and social phenomenon.

Then, in terms of a means-and-end analysis, politeness is readily understood by means. We well know that in being polite we have an end to achieve. The most common example is that whenever we want someone to do us a favor we have to make the request in a polite manner. We say "hello!", to someone, or to shake hands with him, or send him a card on the occasion of Spring festival, or to give him a birthday gift or pat him on the shoulder - all this we do in order to show our good feelings, our friendliness, our intention to maintain harmonious relationships with him. In general, we act politely in order to show our wishes to start a friendly relation with someone, or to maintain it if it is already existing, or to mend it if it is being threatened for some reasons. To maintain the kind of smooth, harmonious interpersonal relationships called for by any human community, politeness serves as a ready means.

Politeness can also be regarded as a restraint apart from being a means to an end, some kind of social norm imposed by the conventions of the community of which we are members. Sometimes we feel that we have to be polite in order to show that we are civilized and cultivated to such an extent that we know what to do to live up to the conventionally recognized social standards so that we will not be accused of being rude or ill -manned. In order to be polite, we have to be tolerant. Under certain circumstances, to meet certain standards, we have to refrain from doing certain things which we would readily do in private.

To sum up, politeness can at once be understood as a social phenomenon, a means to achieve good interpersonal relationships, and a norm imposed by social conventions. So it is phenomenal, instrumental and normative by nature.

In many ways, politeness is universal. It can be observed as a phenomenon in all cultures; it is resorted to by speakers of different languages as a means to an end and it is recognized as a norm in all societies. Despite its universality the actual manifestations of politeness, the ways to realize politeness, and the standards of judgment differ in different cultures. Such differences should be traced back to the origin of the notion of politeness in different cultures.

As a social phenomenon, the evolution of the concept of politeness finds ready reflection in English language, especially in its lexis. It has arisen and evolved under the changing historical conditions. Synonymous with the word 'politeness in English is courteous, urbane and civil. The relatedness between politeness on the one hand and court and city on the other hand and court and city on the other is only too clear and such relatedness is mirrored not uniquely in the English language but also in at least another major European language, German. In German which refers to the locus of its genesis is a living reminder of conditions which gave rise to it, and the German word can hardly be uttered without invoking those conditions. A second term referring to politeness in German that is used alongside was urbanity. This one was taken from Latin. The particular 'urbs' (city) it referred to was Rome, which was the unique image of and pattern for the city in the western world.(Ehlich,1992)

The apparent lexical relatedness between politeness and court and city has been confirmed by the research findings of some scholars. In some particular phase in history the behavior of the townsfolk was considered as polite, and in some other the behavior of those in the court.

To sum up, in the English-speaking culture and the Western world in general, politeness has been closely related to the behavior typical of a certain social location and a certain social group. To be polite, means to live up to a set of conventionalized norms of behavior.

In modern Chinese, the equivalent of politeness is limao, which is believed to have evolved in history from the notion of li. The notion of li originated with the ancient Chinese philosopher and thinker Confucius (B.C.551--479), who lived at a time when the slavery system had disintegrated and there were constant wars between feudal states; the former aristocratic social hierarchy was shattered and chaos reigned over the land. To remedy the situation, Confucius advocated the restoration of li, which referred to the social hierarchy and order of the slave society of the Zhou Dynasty (dating back to 1100 B.C.). To Confucius, it was the model of an ideal society. To restore li, it was necessary to zhengming (to rectify names), i.e. to put each individual in his place according to his social position. Confucius set much store by zhengming because he thought "if names are not properly rectified, speech cannot be used appropriately; if speech is not used appropriately, nothing can be achieved; if nothing is achieved, li cannot be restored..."and consequently social order and hierarchy cannot be maintained. Thus zhengming was an important means to that end.

About two hundred years after Confucius, the word li seemed to have been well established in usage somewhat deviated from the Confucian sense but in a sense very close to its derivative in modern Chinese, i.e.limao. It was found in a book entitled Li Ji (on Li) supposed to be written by a man called Dai Sheng during the West Han Dynasty. In the opening lines are found the following "Speaking of li, humble yourself but show respect to other." If the notion of li advocated by Confucius was interpreted, at the risk of oversimplification, as social appropriacy with regard to one's social status, by the time of Dai Sheng, the notion of li had evolved into social appropriacy by way of self-denigrating and other-respecting. It has ever since become an essential feature of the Chinese notion of politeness and has remained at the core of politeness in the Chinese culture. 
From the above brief exploration of the historicity of the notion of politeness in both the English-speaking culture and the Chinese culture, it has become clear that while the notion of politeness is universal, it has different origins and thus different connotations in different cultures.

\section{Considerable Items Related to Politeness.}

To achieve the goal of politeness, we should consider it from the following aspects:

(1) Considering the social background of the communicator. Generally, the more educated a man is, the more he tends to show his politeness to other people. The more he knows about the suitable ways to show politeness, the better he uses them to be polite to others. Besides, the personality of the communicator is also very important here. Good-tempered person prefers to use "face-saving act" while bad-tempered person prefers "face-threatening act" when they come across the "face-losing condition".

(2) According to the communicative circumstances. Communication is a very complicated process. In formal occasions, people tend to use formal expressions to show politeness, esp. between the new acquaintances. While in informal states, people tend to be casual to show intimacy even if it is in the very moment they meet. And that doesn't mean impoliteness. Look at the following example:

eg.1. A man came into a bar and said to the waiter: "Hi! Buddy! Gimme some Whisky, would ya?"

Although they've never met before, the man used very casual phrases to enclose their relationship. This is a usual way to show friendliness to strangers in similar entertaining places.

(3). "In situations of social distance or closeness, showing awareness for another person's face when that other seems socially distant is often described in terms of respect or deference. Showing the equivalent awareness when the other is socially close is often described in terms of friendliness, camaraderie, or solidarity." (C, Yule. , 1996).

But there are exceptions. For example, people often use family names to call their close friends, and when these people speak to each other, they will use direct offer or request. But sometimes they use very formal expressions in their speech. Look at the following example:

eg.2. Husband to his wife: "Would you be so kind as to hand the bread over to me?"

Surely we know that the wife has just quarreled with the husband and the husband is trying to amuse her in a certain way.

Besides all the aspects discussed above, there's another important point to concern with that is the cultural differences.

\section{Cultural Differences}

Different culture causes different views of values, which affects the criteria of politeness and leads to differences in various aspects.

\subsection{Ways to greet each others and farewells}

The westerners often greet others with a cheerful "Hello!" or something like "How are you?" If they are talking with a stranger, they tend to talk about the weather as a way of greeting. But to Chinese people, they like to ask " Have you eaten?","where are you going ?" , “What brings you here?" or " What are you doing here?" All these would be considered as interferences to privacy for westerners.

When parting, Chinese seldom say "goodbye" as farewells that would be too formal or somewhat distant. Before they leave, Chinese guests like to say "I have to go now." "I am going." or "Stay where you are", and the hosts are used to say "Go slowly", "Come again." to see them off. While two friends departing after they meet on the road, one of them may say " I've got to leave." and the other may say "Let" s chat next time", " Come to see me when you are free." Or "I would visit you if I can." As for westerners, they often say "Goodbye!","See you!" when they part. (Deng Yanchang and Liu Runqing 1989, P170)

\subsection{Addressing terms}

Chinese often use one's occupation to address him to show respect, either in formal or informal occasions when their social status is considered to be high or respectful. e.g. Professor Li , Teacher Zhang, Dean Sun, etc. If their social statuses are considered to be low, such as barber, cleaner, technical worker, cook, plumber and most people in service profession, people will often call them "shifu" instead of their occupations to be polite. To westerners, this is not the same. In formal situations, they often address people who hold high social status with their professions as: Professor Green, Chairman Johnson etc. But they never address people with “teacher or manager". In informal occasions, even a professor or a chairman prefers himself to be called with his given name to show intimacy to others. And they tend to call others like this while a Chinese may feel unpleasant to be called in such a term by unfamiliar person. For example, if a girl named "Yang Liyuan" is called as "Liyuan" or " yuan" by an ordinary friend, she will look on it as an insult. (Deng, Yanchang \& Liu, Runqing, 1989,P171) 
Besides, in China, "little+surname" or "old+surname" is an address to show intimacy but we cannot address foreigners in such a way.

The addressing terms used for strangers are also different. Chinese people like to use family terms to address strangers or people elder than them. For example, children are told to address adults with "aunty" or "uncle"; call old people "granny" or "grandpa", even at the first time they meet. But westerners never call a family outsider with those items. For instance, "Bill, can you get the report to me by tumor row?" The terms "Mr", "Miss", "Mrs.", "sir" and "madam" are widely used among people. "Mr.", "Miss" and "Mrs." are used together with a surname while " sir" and " madam" are often used alone. Another example is "Mr. Lee, there is a phone call for you."

When a Chinese want to draw the interests of a passer-by, he may use " Shifu" to address people of both sexes, but there is no such a term in English. They would say "Pardon me, Madam." Or "Excuse me, Sir." to address different sexes. (Deng, yanchang \& Liu, Runqing, 1989, P172)

\subsection{Ways to praise others}

Look at this dialogue below:

eg.3. (Seeing a beautiful curtain in an American family, the Chinese wants to praise the room settings)

Chinese: "How beautiful the curtain is!"

Hostess: "I made it on my own."

Chinese: "Really? I can't believe it!"

The Chinese used surprising tone to show he really liked the curtain, this strategy works well in China, but the hostess felt insulted. We know the Americans are very confident about themselves. Imagine what they may feel when their self-esteems are being hurt. The hostess thought the Chinese didn't believe she was capable of doing it, and her ability was doubted.

What's more, the westerners like to praise the hostess or the host on their first visit, they consider that to be polite and natural, but it may make the Chinese host be offended, suspicious whether he is interested in the woman.

In most cases, the westerners prefer to be praised over their house, garden, car, wife, decorations and room arrangements etc. esp. something made on their own hands, but often not their children' s beauty or intelligence which is considered as leading the kids to be vanity.

\subsection{Ways to express thanks}

The ways to express thanks are different in China from western countries. Westerners prefer to convey their thanks directly while Chinese like to minimize themselves to achieve the same goal.

eg.4. When you praise them: " How beautiful your dress is! Westerners: "Thanks a lot!"

Chinese: "Really? It" s just an ordinary dress."

eg.5. When they appreciate your help, westerners: "You" re really a great help to me."

"I can" $t$ imagines how I can manage it without you!

"Thank you for enduring so much trouble I brought to you!" "I really appreciate your help!" ...

Chinese: "Sorry to have wasted your time."

"Sorry for having taken up your precious time."

"I" $\mathrm{m}$ not at ease for bringing your so much trouble."

eg.6. Westerner's appreciations: "thank you. You have helped me a lot today. You must have been very tired." The other answered "it's my pleasure to help you. But I'm not tired at all."

The westerner is trying to maximize the communicator's help to be polite while the Chinese humbles himself to show gratitude. So it happens when a foreigner praises a Chinese woman for her beautiful dress, if the Chinese woman uses a Chinese way to show politeness as in e.g.3, her answer might be considered as minimizing the westerner' $s$ ability to appreciate for he had shown great surprise over such an ordinary dress. You know what he would feel!

Another example is after a good dinner, you should express the thanks to the host. Chinese usually say "I'm so sorry; I have given you so much trouble." Westerners usually say "thank you so much for a wonderful evening."

\section{Politeness and Culture Values}

\subsection{Considerations of privacy}

Privacy is regarded more important value in English-speaking culture than in China. What is considered as an act of politeness in the Chinese culture might simply be regarded as an intrusion upon a person's privacy by an 
English-speaking person. Mr. Gu has included 'attitudinal warmth' as one of the four aspects underlying politeness in the Chinese culture. To show warmth and concern for others is considered as a polite act. Different people hold different views about what privacy is. That is why when two Chinese meet; their conversation may include age, marriage, family, occupation and even incomes, all of which are considered as privacy to westerners. The Chinese think that they are being polite by showing concern for other people, and asking all these questions will help shorten the social distance between themselves and their interlocutors. But speakers of English, should they be asked all such questions, would feel their interlocutor is rudely encroaching upon their privacy.

Look at the following conversation:

eg.7. "(I feel close to the young man now.) I--- an old man

He--- a young man

I: How old are you? He: Nineteen. I: How long have you been in the army? He: One year.

I: How did you join the revolution? He: I followed the army voluntarily when they retreated to the north.

I: Who else are in your family? He: My mother, father, brother, sister and my aunt.

I: Are you married? ... (c.f Ru, Zhijuan “ Liliaceous”)(c.f. Gu 1992)

This seems to be an interview or an interrogate for a westerner, otherwise it may be taken as an insult, but it's a daily conversation in China. In China, people like to talk about their age, marriage, children, salaries etc. even on their first meet. That may seem somewhat ridiculous for the westerners, who never like things like this to be asked, for they look on them as privacy.

In the western countries, the homes and offices, desks and desk drawers are private territory. The letters, documents, journals or even newspapers on top of the desk belong to the person whose desk it is. Without permission, one should not pick them up and read or look at them. The vast majority of people will gladly lend you what is theirs-just ask. By the way, it is also very impolite to read over someone's shoulder.

\subsection{Considerations of individualism}

Individualism spelled out in detail by the seventeenth-century English philosopher John Locke, that each individual is unique, special, completely different from all other individuals, and "the base unit of nature". Individualism is considered of great value in English-speaking countries, it is closely related with the history and the culture. It usually refers to the freedom, right and independency of an individual. It is regarded that the actions showing respect to individualism as polite ones. Chinese, who have been overwhelmed by feudalism for more than two thousand years, is hard for them to understand individualism. So what is considered to be "threatening act" to "Negative face" "in western countries may be a natural or welcomed act in China. For example, Chinese people will not think "offering something", "offering some help", or "sending some invitations" to be an insult to individualism or a "face-threatening act". Chinese people consider those actions to be of care or sincerity; they even think sometimes they have to force you to accept to show their sincerity. Thus it's common to see Chinese people add food into a guest's plate constantly to show enthusiasm; oblige others to accept gifts to show sincerity, etc. They are all considered to be polite in Chinese culture but the opposite in western culture. Westerners with a strong notion think that there is something wrong with someone who fails to demonstrate individualism. The individual notion is deeply rooted in the English-speaking culture.

\subsection{Considerations of taboos}

Taboos are the words that are closely bounded to cultures. Most of the items mentioned above may be looked on as taboos in daily conversations. Take the item mentioned in 'Considerations of Privacy' "age" as an example, in western countries, woman's age is a taboo in daily conversations, never will you hear a woman ask you questions like "How old are you?" during your chatting

And in western countries, the aged people do not like the young people to call them as "old man", they like "senior man" or "senior citizen" better. They do not like others help at all. Because if he accepts your help, it seems that he need other's help and sympathy. It means they are old. Also there are many taboos we should remember when talking with westerners. Such as the questions about religions, salary, children, marriages, sex, etc. in Chinese traditional culture, there also have some taboos. For example, in the Spring Festival, people forbid to say some words such as "broken" and "death". They are afraid that these words may take away their whole-year fortune. So to politeness, we should remember these taboos.

\section{Conclusion}

In a word, when we are communicating with people from different cultures, it is best to consult what is appropriate in their culture and act with regard to that, so as to avoid misunderstandings caused by culture differences. Because of the limitation of the author, this paper has not collected data in other more specific aspects, e.g. gender difference, taboo words, etc. That may be covered in researches afterwards. And I hope, with much understanding of the politeness 
principle, we can have a better communication with others.

\section{References}

Deng, Yanchang, et al. (1989). Language and Culture. Beijing: Foreign Language Teaching and Research Press.

Gu, Yueguo. (1992). Politeness, Pragmatics and Culture. Beijing: Foreign Language Teaching and Research Press. Gu, Yueguo. (1990). Politeness Phenomenon in modern Chinese, Journal of Pragmatics, 14: 237-257.

He, Zhaoxiong. (2000). A New Introduction to Pragmatics. Shanghai: Shanghai Foreign Language Teaching Press. Leech. (1983). Longman: Principles of Pragmatics. 